\title{
RUSSIA'S FOREIGN TRADE IN OCTOBER 2015
}

\section{N.Volovik}

In 2015, the RF foreign economic activity was subject to a set of negative factors: significant reduction of prices on all tradable commodities, contraction of external demand due to slowdown of the world economy, compression of domestic demand due to a fall of income and investment. Consequently, contraction of the Russian foreign trade turnover has turned out to be stronger in 2015 than during 2009 crisis.

In October 2015, Russia's foreign trade main indicators have demonstrated negative dynamics. In October 2015, Russia's foreign trade turnover calculated on the balance of payments methodology mounted to $\$ 44.4$ bn down $34.7 \%$ against the same indicator last year.

In October 2015, export amounted to $\$ 27.2 \mathrm{bn}$, which is less than in October 2014 by $34.4 \%$. Herewith, export to far abroad countries has shrunk by $36.9 \%$ and to CIS members - by $17.6 \%$. Imports fell by $36 \%$ to $\$ 17.2 \mathrm{bn}$ against October 2014. Imports have contracted both from far abroad countries (by $36.3 \%$ ) and from CIS members (by 33.8\%). Trade balance was positive to the tune of $\$ 10.1$ bn down $29.2 \%$ on October 2014 .

2015 turned out to be very hard for tradable commodities: nearly all tradable commodities experience excess supply over demand. From the turn of the year, Bloomberg Commodity Index (BCOM) shrank by $27 \%$, which is the lowest indicator since 2008. On 7 December 2015, Bloomberg Commodity Index fell below 80 points for the first time since 1999.

In January-October 2015, price of Brent stood at $\$ 53.7$ per barrel down 47.5\% against January-October 2014 ( $\$ 102.3$ per barrel). In December 2015, price of Brent plunged below $\$ 37$ per barrel. Main cause for this was the unwillingness of OPEC members to reduce surplus amount of oil on the market. The OPEC summit held in Vienna on 4 December 2015 decided to leave

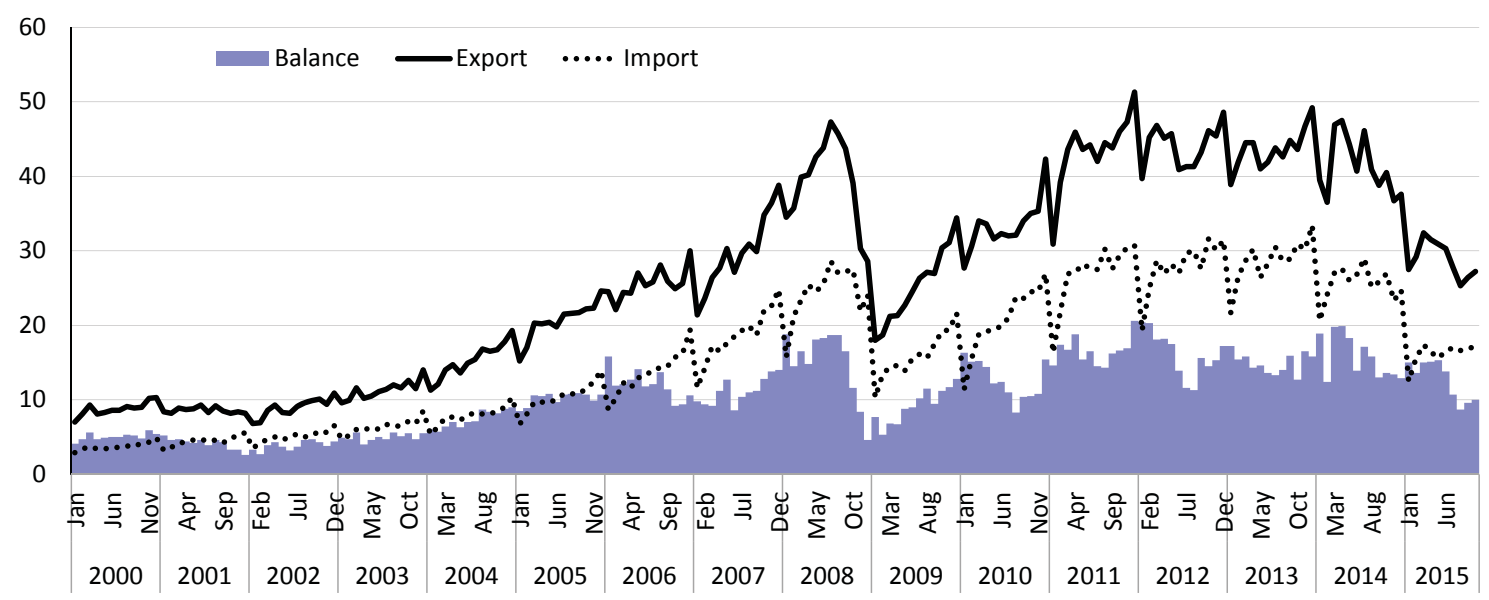

Source: CB RF.

Fig. 1. Russia's key foreign trade indicators (USD billion) 
the production quota unchanged. From December 2011, OPEC production quota amounted to $30 \mathrm{mb} / \mathrm{d}$, however real production in the intervening one and a half years exceeds this amount (by $1.3 \mathrm{mb} / \mathrm{d}$ in October). Moreover, Iran's intentions to sell crude at a price below $\$ 30$ per barrel together with market expectations for lifting crude export ban by the US and the FRB's decision to raise the target range for the federal funds rate by 25 points, which should result in strengthening of the American currency exerted pressure on crude quotations. In medium-term, FRB is going to hike the discount rate to $1.5 \%$ in 2016 and to $2.5 \%$ in 2017.

Last time the rate was raised in June 2006. In the course of 2008, it was falling 7 times, and in December 2008, it was set at the historical low level of $0-0.25 \%$ where it stayed during 7 years.

Discount rate hike in the US means subsequent increase of the dollar exchange rate in relation to other currencies as well as reduction of prices on tradable commodities. Thus, in 2016 , one should expect further negative price trend.

In October 2015, Urals price moved up against September 2015 by $0.2 \%$ and amounted to $\$ 46.8$ per barrel. Compared to October 2014, price of Urals fell by $45.9 \%$. During 10 months of 2015 , price of Urals decreased against the same period last year by $48.0 \%$ to $\$ 53.6$ per barrel.

In November 2015, the President of the Russian Federation Vladimir Putin signed Law "On Introduction of Amendments to the Law 'On Customs Tariff'", which leaves the oil export duty for 2016 at the 2015 level in the amount of $42 \%$. Previously, it was envisaged to reduce it to $36 \%$ within the framework of "tax manoeuvre".

From 15 November to 14 December 2015, average price of Urals came to $\$ 39.40619$ per barrel or $\$ 287.7$ per ton. From 1 January 2016, according to effective calculation formula for the oil export duty will come to $\$ 73.3$ per ton down $17.1 \%$ on December ( $\$ 88.4$ per ton). From January 2016, export duty of petrol will be $\$ 44.7$ per ton against $\$ 68.9$ per ton in December, on light petroleum products, including diesel oil $-\$ 29.3$ per ton (in December $\$ 42.4$ per ton). Export duty on dark petroleum products including heating oil and bitumen will be $\$ 60.1 \%$ per ton in January against $\$ 67.1$ per ton a month earlier.

Metal market posted downward trend, which was due to growing production volumes amid falling demand on the part of the largest consumerChina. According to the London Metal Exchange, in October 2015 against October 2014, 2015 price quotations on nickel and copper up $4.5 \%$ and $0.3 \%$,

Table 1

MONTHLY AVERAGE GLOBAL PRICES IN SEPTEMBER THEN-YEAR

\begin{tabular}{|l|l|l|l|l|l|l|l|l|l|l|}
2005 & 2006 & 2007 & 2008 & 2009 & 2010 & 2011 & 2012 & 2013 & 2014 & 2015 \\
\hline
\end{tabular}

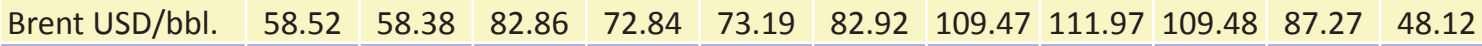

Natural

\begin{tabular}{|c|c|c|c|c|c|c|c|c|c|c|c|}
\hline gas*, USD/1 & 7.28 & 8.97 & 9.16 & 15.93 & 7.6 & 8.28 & 11.42 & 11.58 & 11.37 & 9.77 & 6.43 \\
\hline op & & & & & & & & & & & \\
\hline nium, & רכר & 2659 & רגו & 1.4 & 77.8 & 2447.0 & 2172.0 & 1974.3 & 14.6 & 1946.2 & 1 \\
\hline ickel, USD/t & 2403 & 32348 & 30999 & 12140 & 18514 & 22167 & 18886 & 17169 & 14118 & 15812 & 10317 \\
\hline
\end{tabular}

* European market, average contract price, franco-border.

Sources: World Bank 
respectively. Aluminium prices, on the contrary, down $4.1 \%$. Compared to October 2014 , nickel prices shrank by $34.4 \%$ and copper - by $22.5 \%$, aluminium - by $21.4 \%$. In January-October 2015 , prices on aluminium shrank against the same period 2014 , by $7.8 \%$, on copper -by $18.1 \%$, on nickel - by $27.2 \%$.

In October 2015, the Food Price Index FAO averaged 162 points, up 6 points against the previous month. This is the sharpest Index growth since July 2012. Index growth is due to a significant increase of prices on: sugar, vegetable oils and dairy products, meanwhile prices of cereals moved up slowly and meat prices remained on hold. In comparison with 2014, the Food Price Index in October 2015 down 30.7 points.

In 2015, foreign trade indices posted steep downfall against 2009. In January-October 2015, Russia's foreign trade turnover calculated on the balance of payments methodology amounted to $\$ 448.1$ bn down $34.4 \%$ against the same indicator last year. Over 10 months of 2015, Russian exports contracted by $32 \%$ to $\$ 287.2 \mathrm{bn}$ against the same period last year. Over the same period, Russian imports shrank at a higher pace on exports amid economic recession and rouble depreciation as well as in the wake of international trade sanctions. Consequently, in January-October 2015, trade balance was positive amounting to \$126.3bn but shrank against January-October 2014 by $22.2 \%$.

Over 10 months of 2015 against 10 months 2014, regional pattern of Russia's foreign trade was subject to changes: the share of EU countries fell (from 484 to $45.3 \%$ ). The share of CIS members remained at 2014 level $12.5 \%$. Herewith, the share of APEC member went up from 26.6 to $27.9 \%$.

The share of European Union in the RF trade turnover went on falling due to the import ban imposed by Russia in august 2014 on a number of food products from EU, USA, Canada, Australia and Norway. The highest fall of imports is registered from the following countries: Estonia - by $65.9 \%$, Lithuania - by $58.5 \%$, Greece - by $54.6 \%$ and Great Britain - by $51.9 \%$.

Russia has negative trade balance with 20 countries whose share in the total Russia's turnover constituted $21.6 \%$. The largest negative balance Russia has with China (-\$5 bn), USA (-\$1.4 bn), Indonesia (-\$0.9 bn), Thailand (-\$0.7 bn), Brazil ( $\$ 0.7 \mathrm{bn})$, and Argentina (-\$0.6 bn).

The WTO's 10th Ministerial Conference was held in Nairobi, Kenya, from 15 to 19 December 2015. The Ministerial Conference was held within the Doha round, which commenced in 2001 and was called to resolve trade contradictions between countries with different level of economic development by way of promoting developing economies growth via simplified access to markets. That round envisaged a large-scale update of effective trade agreements both on goods and services as well as protection of intellectual rights. However, due to disagreements between parties on key issues resulted in the lack of progress in resolution of the challenges facing multilateral trade system.

However, this year certain progress has been accomplished. The WTO's 10th Ministerial Conference final declaration introduced a ban on agricultural export subsidies. Negotiations regarding this issue have been held over twenty years and only this year all WTO members have come to an acceptable solution. Countries, which have not applied export subsidies over recent three years, blow their chances for subsidies. Under the decision, developed members have committed to remove export subsidies immediately (at the same time, they receive a transition period for products previously on the 
notification list for export subsidies and reviewed by the WTO Committee on agriculture). The developing countries will do so by 2018. Developing members will keep the flexibility to cover marketing and transport costs for agriculture exports until the end of 2023, and the poorest and food-importing countries would enjoy additional time to cut export subsidies till 2030. This is the most significant decision on agriculture for the entire 20-year history of the WTO.

Russia has not applied export subsidies for agricultural products and during the accession to WTO took an obligation not to apply direct export subsidies for agricultural products.

The conference also took a decision to reduce tariffs on IT technologies, which expands the current Information and Technology Agreement, ITA adopted in 1996, and agreed on the timetable for implementing a landmark deal to eliminate tariffs on 201 information technology products, including: next generation semiconductors, play stations, MRI scanners, computer assisted tomography, among other. According to some estimates, ITA-II will expand world trade by $\$ 1.3$ billion per year.

The final declaration "reaffirmed the central role of the WTO in international trade governance". It also underscores that the central character of multilateral trade system does not hamper the development of regional integration agreements but all regional trade agreements do not replace multilateral system but compliment it.

The WTO $10^{\text {th }}$ Ministerial Conference saw Liberia and Afghanistan to join this organization. Thus, the WTO numbers 164 countries as its members. 